Research Article

\title{
Effect of Nebivolol on MPTP induced Parkinson's Disease in Mice
}

\author{
Karthigadevi.K*, Anbazhagan. $\mathbf{S}^{\mathbf{1}}$, Jajjara Gopi Sudheer kumar², Kavimani.S ${ }^{2}$ \\ *1 Department of Pharmacology, Surya School of Pharmacy, Vikravandi, Villupuram, Tamilnadu, India. \\ 2 Department of Pharmacology, Mother Theresa Post Graduate and Research Institute of Health Sciences, Puducherry, India. \\ *Corresponding author's E-mail: karthe129@gmail.com
}

Received: 17-04-2021; Revised: 15-06-2021; Accepted: 24-06-2021; Published on: 15-07-2021.

\section{ABSTRACT}

Parkinson's disease is the major neurodegenerative disorder, which is due to the loss of dopaminergic neurons in the brain and results in bradykinesia, rigidity, tremor and instable posture. Oxidative stress, Inflammation, Apoptosis has been implicated in the molecular etiopathogenesis of Parkinson disease. In the present study, Nebivolol, a Cardioselective $\beta$-blocking agent which is also reported as an antioxidant, anti-inflammation, anticonvulsant, inhibition of apoptosis and protective effects on gastric ulcer. Hence, nebivolol has been tested for its antiparkinson activity against 1-Methyl, 4-Phenyl-1,2,3,6-Tetrahydropyridine (MPTP) induced model of Parkinson disease in mice. From this study, the result shown that the nebivolol exerts its beneficial effect against MPTP induced Parkinson's disease by virtue of its antioxidative, anti-inflammatory and by increases the Dopamine levels in the brain.

Keywords: Parkinson's disease, MPTP, Nebivolol, Dopamine

QUICK RESPONSE CODE $\rightarrow$

DOI:

10.47583/ijpsrr.2021.v69i01.020

DOI link: http://dx.doi.org/10.47583/ijpsrr.2021.v69i01.020

\section{INTRODUCTION}

$\mathrm{N}$ eurodegenerative (NDG) disorders are a heterogeneous group of diseases of the nervous system, including the brain, spinal cord, and peripheral nerves that have many different etiologies. Many are hereditary, some are secondary to toxic or metabolic processes, and others result from infections. Neurodegenerative disorders include, Alzheimer disease, Parkinson's disease, Amyotrophic Lateral Sclerosis and Huntington's disease.

Parkinson's disease (PD) is a movement disorder which is manifested by any combination of tremor at rest, rigidity, bradykinesia, and loss of postural reflexes. The population over the age of 65 has PD. The annual incidence rates are estimated at approximately 20 per 100,000 populations. ${ }^{1}$ This is slow, progressive disease and is characterized by the loss of dopaminergic neurons in the pars compacta of the substantia nigra (SN) and intraneuronal cytoplasmic inclusions called Lewy bodies. The causes for degeneration of DA neurons can be assumed that interaction between external toxin, arise from the environmental factors [carbon monoxide poisoning, hydrogen sulfide, Manganese, methanol, MPTP (1-methyl-4-phenyl-1-2-5-6tetrahydropyridine)] and internal toxin, arise from normal metabolism and genetic factors. ${ }^{2}$
The Neuropathological hallmark of PD includes, Selective degeneration of dopamine (DA) neurons in the nigrostriatal system, Mitochondrial dysfunction and the consequent oxidative stress, including toxic oxidized DA species and Neuroinflammatory process occurs due to the activation of myeloperoxidase enzymes. ${ }^{3}$ The current approach for the management of PD involves by suppressing the disease progression rather than achieving a cure. ${ }^{4}$ This approach is unsatisfactory, given the high prevalence of PD worldwide, with its concomitant morbidity and mortality improved understanding of the underlying mechanisms and novel therapeutics are crucial.

Therefore, drugs which can modulate reactive oxygen species may be potentially useful in the management of parkinsons disesase. One such drug is Nebivolol, which is more potent, highly selective and long acting $\beta 1$ adrenoceptor blocking agent with reported actions like antioxidant 5,6, anti-inflammatory action ${ }^{7}$, inhibition of apoptosis $^{8}$, and it also reported as to reduce the nitrite level in the brain by decreasing the oxidative stress ${ }^{9}$ and exert anticonvulsant action. ${ }^{10}$ These effects may be attributed in part to the free radical scavenging activity of Nebivolol. With this background we decided to evaluate the effect of Nebivolol on 1-Methyl, 4-Phenyl-1,2,3,6Tetrahydropyridine (MPTP) induced Parkinson disease in mice.

\section{MATERIALS AND METHODS}

\section{Animals}

Swiss Albino mice (25-35g) were used in the present study. Animals were procured from the animal house of Mother Theresa Post Graduate and Research institute of Health Sciences, Puducherry. They acclimatized to the laboratory condition for 5 days before behavioral studies. The animals were housed in a group of 3 per cage under well-controlled 
conditions of temperature $\left(22 \pm 2^{\circ} \mathrm{C}\right)$, humidity $(55 \pm 5 \%)$ and the animals had access to pellet diet and water ad libitum was provided with alternate light and dark cycles of $12 \mathrm{~h}$ each. The protocols of the experiment were approved by the institutional Animal ethical Committee (IAEC) as per the guidance of the committee for the purpose of control and supervision of experiments on Animals (CPCSEA).

\section{Drugs and Chemicals}

1. Nebivolol drug sample was obtained from Hetero Drugs Limited, Andhra Pradesh, India.

2. MPTP (salt) was obtained from Sigma Chemical CO. USA and all other chemicals were of analytical grade

3. Rasagiline was obtained from sun Pharmaceutical Industry, Samba, India.

\section{Dose Selection}

1. With reference to the Paget and Barnes conversion table ${ }^{11}$, the test and standard drug doses were calculated

2. MPTP doses were selected according to the earlier research work carried on. ${ }^{12}$

\section{Experimental Design}

The animals were divided into five groups $(n=5)$ and the treatment schedule was 7days. The groups were as follows

\section{Group 1}

Normal control: Vehicle (CMC, 0.25\%)

\section{Group 2}

Negative control- MPTP (20mg/kg, i.p.) of four injections at 2hour intervals.

\section{Group 3}

Positive control, Rasagiline $(0.1 \mathrm{mg} / \mathrm{kg}$, i.p.) on the initial day, 30 min prior to the first injection of MPTP and once a day for another 6 days of the experimental period.

\section{Group 4}

Test-1, Nebivolol-I $(0.65 \mathrm{mg} / \mathrm{kg}$, i.p.) on the initial day, 30 min prior to the first injection of MPTP and once a day for another 6 days of the experimental period.

\section{Group 5}

Test-2, Nebivolol-II (1.3mg/kg, i.p.) on the initial day, 30 min prior to the first injection of MPTP and once a day for another 6 days of the experimental period.

\section{Pharmacological Activities of Parkinson's Disease}

\section{Behavioral Studies}

At the end of the experimental period (i.e., on the $7^{\text {th }}$ day), the following Behavioral parameters (Motor integration tests) were evaluated

\section{Rotarod test}

Motor coordination was measured on the seventh day using an automated rotarod. The animals were exposed to 10 trials on a rotating rod at $10 \mathrm{rpm}$ at $5 \mathrm{~min}$ intervals with a cut off time of 180 seconds. The rotarod was divided into four compartments, which could allow four mice at a time. The average retention time on the rod was calculated. ${ }^{13}$

\section{Hang test}

The grid was then inverted so that the mice were allowed to hang upside down. The grid was mounted $20 \mathrm{~cm}$ above a hard surface to discourage falling, but not leading to injury in case of a fall. The apparatus was equipped with a 3 -inch wall to prevent the animals from transversing to the upper side of the grid. The animals were required to stay on the grid for 30 seconds and 10 chances were given with $1 \mathrm{~min}$ intervals and the maximum hanging time was recorded. ${ }^{14}$

\section{Catatonic Behaviour Test}

In this test, the development and severity of the four stages of catatonia were observed and scored as follows: Stage 1, mice moves when placed on the table, score $=0$; Stage 2, mice moves only when touched or pushed, score $=0.5$; Stage 3, mice placed on the table with front paws set alternately on a $3 \mathrm{~cm}$ high block fails to correct the posture in $10 \mathrm{~s}$, score $=0.5$ for each paw with a total of 1 for this stage; State 4, mice fails to move when the front paws are placed alternately on a $6 \mathrm{~cm}$ high block, score $=1$ for each paw with a total score 2 for this stage. Thus, the maximum possible score would be 3.5 reflecting full catatonia. Lesser score would mean an apparently lesser degree of catatonia. ${ }^{15}$

\section{Biochemical Analysis}

\section{Preparation of Tissue Homogenates}

After completing the behavioral test, the animals were sacrificed by cervical decapitation before stunning. Then the brains were excised immediately and serially sectioned, and then the tissue was homogenized in ice cold $0.1 \mathrm{M}$ phosphate buffer $\left(\mathrm{P}^{\mathrm{H}}\right.$ 7.4) The homogenate $(10 \%$ $\mathrm{w} / \mathrm{V}$ ) was then centrifuged at $3000 \mathrm{rpm}$ for $15 \mathrm{~min}$ at $4^{\circ} \mathrm{C}$ and the supernatant so formed was used for further biochemical analysis. ${ }^{12}$

\section{Measurement of Dopamine}

To the $0.2 \mathrm{ml}$ of aqueous phase, $0.05 \mathrm{ml} 0.4 \mathrm{M} \mathrm{HCl}$ and 0.1 $\mathrm{ml}$ of Sodium acetate buffer (PH 6. 9)were added, followed by $0.1 \mathrm{ml}$ iodine solution( $0.1 \mathrm{M}$ in ethanol) for oxidation. The reaction was stopped after $2 \mathrm{~min}$ by addition of $0.1 \mathrm{ml}$ $\mathrm{Na}_{2} \mathrm{SO}_{3}$ solution. $0.1 \mathrm{ml}$ Acetic acid is added after $1.5 \mathrm{~min}$. The solution was then heated to $100^{\circ} \mathrm{C}$ for $6 \mathrm{~min}$ when the sample again reached room temperature, excitation and emission spectra were read from the spectrofluorometer. The readings were taken at 330-375 $\mathrm{nm} .^{16}$ 


\section{Measurement of lipid peroxidation}

The extent of lipid peroxidation in the brain was determined quantitatively by performing the method as described by wills. Aliquots of $0.5 \mathrm{ml}$ distilled water were added with $1 \mathrm{ml}$ of $10 \%$ trichloroacetic acid and were added with $0.5 \mathrm{ml}$ of brain tissue homogenate. This is centrifuged at $3000 \mathrm{rpm}$ for $10 \mathrm{~min}$. To the $0.2 \mathrm{ml}$ supernatant, $0.1 \mathrm{ml}$ thiobarbituric acid $(0.375 \%)$ was added. Total solution is placed in water bath at $80^{\circ} \mathrm{C}$ for $40 \mathrm{~min}$ and cooled at room temperature. Absorbance was read at $532 \mathrm{~nm}$. The concentration of MDA in the supernatant was determined from the standard curve. The results were expressed as nmol MDA/mg protein. ${ }^{17}$

\section{Measurement of Catalase}

Catalase (CAT) activity was assessed by the method of Luck, wherein the breakdown of hydrogen peroxides was measured. Briefly, the mixture consisted of Potassium phosphate buffer $(2.25 \mathrm{ml})\left(65 \mathrm{mM}, \mathrm{P}^{\mathrm{H}} 7.8\right)$ and $100 \mu \mathrm{l}$ of the brain homogenate were incubated at $25^{\circ} \mathrm{C}$ for $30 \mathrm{~min}$. An aliquot of $650 \mu \mathrm{H} \mathrm{H}_{2} \mathrm{O}_{2}(7.5 \mathrm{mM})$ was added to the brain homogenate to initiate the reaction. The absorbance was measured at $240 \mathrm{~nm}$ for 2-3 min and the results were calculated by using the standard curve which is expressed as CAT $\mu \mathrm{mol} / \mathrm{min} / \mathrm{mg}$ protein. ${ }^{18}$

\section{Measurement of Glutathione (GSH)}

Glutathione (GSH) level was estimated by Ellman method. The brain homogenate and 10\% TCA (1:1) were mixed and kept on ice for $10 \mathrm{~min}$, then centrifuged at 2,000 g for 10 min at $4^{\circ} \mathrm{C}$ and supernatant was collected and used for GSH estimation. To $0.1 \mathrm{ml}$ of supernatant, $2 \mathrm{ml}$ of phosphate buffer ( $\mathrm{P}^{\mathrm{H}}$ 8.4), $0.5 \mathrm{ml}$ of 5,5- dithiobis (2-Nitrobenzoic acid) (DTNB) and $0.4 \mathrm{ml}$ of double distilled water ere added and the mixture was shaken vigorously on vortex. The absorbance was read at $412 \mathrm{~nm}$ using UV visible spectrophotometer. GSH concentration was calculated by using standard curve prepared with reduced glutathione and expressed as $\mathrm{nmol} / \mathrm{mg}$ protein. ${ }^{19}$

\section{Estimation of nitrite}

The accumulation of nitrite in the supernatant, an indicator of the production of nitric oxide was determined by a colorimetric assay with Greiss reagent $(0.1 \% \mathrm{~N}-(1-$ napththyl) ethylene diamine dihydrochloride, $1 \%$ sulphanilamide and $5 \%$ phosphoric acid.) according to. Equal volumes of the supernatant and the Greiss reagent were mixed and the mixture was incubated for $10 \mathrm{~min}$ at room temperature in the dark. The absorbance was measured at $540 \mathrm{~nm}$ using Perkin Elmer Lambda 20 spectrophotometer. The concentration of nitrite in the supernatant was determined from sodium nitrite standard curve and the results were expressed as $\mu \mathrm{mol} / \mathrm{mg}$ protein. ${ }^{20}$

\section{Estimation of brain Myeloperoxidase (MPO) level}

Measurement of myeloperoxidase (MPO) activity was carried out as marker of brain neutrophil infiltration and hence inflammation. Brain myeloperoxidase (MPO) was assayed with the method given by Barone with slight modifications. The reaction mixture contains supernatant collected was mixed with $\mathrm{O}$ phenylenediamine $(660 \mu \mathrm{g} / \mathrm{ml}$ in phosphate buffer) and $300 \mathrm{mM} \mathrm{H} \mathrm{O}_{2}$ was added to initiate the reaction. MPO activity was studied spectrophotometrically at 460 $\mathrm{nm}$. MPO activity was expressed as units/gm protein. ${ }^{21}$

MPO was calculated according to the given formula,

\begin{tabular}{|l|}
\hline MPO activity $=\mathrm{X} /$ weight of piece of tissue \\
Where, $\mathrm{X}=10 \times$ Absorbance / volume of
\end{tabular}
supernatant taken in final reaction.

\section{Protein estimation}

The protein content was estimated by Lowry's method $^{\mathbf{2 2}}$ by using reagent kit (Beacon Diagnostic Pvt, Ltd., Navsari, India)

\section{Statistical analysis}

Results were expressed as Mean \pm SEM and the statistical analysis of data was done using one-way ANOVA followed by Tukey's test. The probability level less than 0.05 was considered as statistically significant.

\section{RESULTS}

The results of rotarod test in mice after administration of Nebivolol on $7^{\text {th }}$ day are given in (Table no.1). In the MPTP treated group, the retention time (Sec) was found to be $41.61 \pm 1.80$ respectively. Nebivolol at lower doses $(0.65 \mathrm{mg} / \mathrm{kg})$ and higher doses $(1.3 \mathrm{mg} / \mathrm{kg})$ produced significantly $(P<0.01)$ increased in retention time by rotarod test.

The results of Hang test in mice after administration of Nebivolol on $7^{\text {th }}$ day are given in (Table no.1). In the MPTP treated group, the Hanging time (Sec) was found to be $11.60 \pm 1.07$ respectively. Nebivolol at lower doses $(0.65 \mathrm{mg} / \mathrm{kg})$ and higher doses $(1.3 \mathrm{mg} / \mathrm{kg})$ produced significantly $(\mathrm{P}<0.05)$ increased in hanging time by Hang test.

The results of Catatonic behavior test in mice after administration of Nebivolol on $7^{\text {th }}$ day are given in (Table no.1).In the MPTP treated group, the catatonic score was found to be $3.50 \pm 0.0$ at 5-, 15- and 30minutes time interval respectively. Nebivolol at lower doses $(0.65 \mathrm{mg} / \mathrm{kg})$ showed more significant $(P<0.001)$ and higher doses $(1.3 \mathrm{mg} / \mathrm{kg})$ produced significant $(P<0.01)$ decreased score in catatonic test.

Thus, both doses of Nebivolol produced significant effect in all the three models of behavioral test. Hence Nebivolol shows Antiparkinson activity against MPTP induced Parkinsonism in mice. 
Table 1: Effect of Nebivolol on Behavioral Parameters in mice against MPTP on the Treatment of 7th day

\begin{tabular}{|c|c|c|c|c|c|}
\hline \multirow{2}{*}{$\begin{array}{l}\text { Treatment Groups } \\
\qquad(\mathrm{mg} / \mathrm{kg})\end{array}$} & \multirow{2}{*}{$\begin{array}{l}\text { Retention time } \\
\text { (Sec) by Rotarod }\end{array}$} & \multirow{2}{*}{$\begin{array}{c}\text { Hanging time } \\
\text { (Sec) by Hang } \\
\text { test }\end{array}$} & \multicolumn{3}{|c|}{ Severity of Catatonia (Score) by Wooden Block } \\
\hline & & & $5 \mathrm{~min}$ & $15 \mathrm{~min}$ & $30 \mathrm{~min}$ \\
\hline $\begin{array}{c}\text { Control } \\
\text { (CMC 0.25\%) }\end{array}$ & $80.00 \pm 1.53$ & $28.60 \pm 0.74$ & $2.10 \pm 0.10$ & $2.00 \pm 0.0$ & $2.00 \pm 0.0$ \\
\hline & $41.61 \pm 1.80 * *$ & $11.60 \pm 1.07^{*}$ & $3.50 \pm 0.0 * *$ & $3.50 \pm 0.0 * *$ & $3.50 \pm 0.0 * *$ \\
\hline $\begin{array}{c}\text { MPTP (20mg/kg,i.p.) } \\
+ \\
\text { Rasagiline (0.1mg/kg,i.p.) }\end{array}$ & $93.30 \pm 2.67^{* \#}$ & $27.20 \pm 0.86^{\#}$ & $2.70 \pm 0.12^{* \#}$ & $3.00 \pm 0.0^{\#}$ & $3.00 \pm 0.0^{\#}$ \\
\hline $\begin{array}{c}\text { MPTP (20mg/kg,i.p.) } \\
+ \\
\text { Nebivolol (0.65mg/kg,i.p) }\end{array}$ & $72.18 \pm 1.84^{\#}$ & $18.20 \pm 0.73^{\# \#}$ & $2.60 \pm 0.10 * \#$ & $2.90 \pm 0.18 * \#$ & $3.00 \pm 0.15^{\#}$ \\
\hline $\begin{array}{c}\text { MPTP (20mg/kg,i.p.) } \\
+ \\
\text { Nebivolol (1.3mg/kg,i.p.) }\end{array}$ & $88.83 \pm 2.86^{\#}$ & $21.00 \pm 0.70^{\# \#}$ & $2.80 \pm 0.12^{* \#}$ & $3.00 \pm 0.0^{\#}$ & $3.00 \pm 0.0^{\#}$ \\
\hline
\end{tabular}

Values are expressed as Mean \pm SEM, $n=5 ; * * P<0.001,{ }^{*} \mathrm{P}<0.05$ Vs control; ${ }^{* \#} \mathrm{P}<0.001,{ }^{\#} \mathrm{P}<0.01$ and ${ }^{\# \#} \mathrm{P}<0.05 \mathrm{Vs}$ MPTP group (one-way ANOVA followed by Tukey's multiple comparison test)

Table 2: Effect of Nebivolol on Biochemical analysis in mice against MPTP induced Parkinson's after 7 days treatment

\begin{tabular}{|c|c|c|c|c|c|c|}
\hline $\begin{array}{l}\text { Treatment } \\
\text { Groups } \\
\text { (mg/kg) }\end{array}$ & $\begin{array}{c}\text { MDA } \\
\text { (nmol MDA /mg } \\
\text { Protein) }\end{array}$ & $\begin{array}{c}\text { MPO } \\
\text { (units/gm } \\
\text { protein) }\end{array}$ & $\begin{array}{c}\text { GSH } \\
\text { (nmol/mg } \\
\text { protein) }\end{array}$ & $\begin{array}{c}\text { Catalase } \\
\left(\mu \mathrm{mol} \mathrm{H}_{2} \mathrm{O}_{2} /\right. \\
\mathrm{min} / \mathrm{mg} \\
\text { protein) }\end{array}$ & $\begin{array}{c}\text { Nitrite } \\
\text { ( } \mu \mathrm{mol} / \mathrm{mg} \\
\text { protein) }\end{array}$ & $\begin{array}{l}\text { Protein } \\
\text { (mg/gm } \\
\text { tissue) }\end{array}$ \\
\hline $\begin{array}{c}\text { Control } \\
\text { (CMC 0.25\%) }\end{array}$ & $42.48 \pm 2.28$ & $52.70 \pm 2.38$ & $13.05 \pm 0.35$ & $71.29 \pm 1.02$ & $7.80 \pm 0.54$ & $1.11 \pm 0.09$ \\
\hline $\begin{array}{c}\text { MPTP } \\
(20 \mathrm{mg} / \mathrm{kg} \text {,i.p.) }\end{array}$ & $136.9 \pm 3.59^{\wedge}$ & $81.46 \pm 2.11^{\wedge}$ & $3.59 \pm 0.30^{\#}$ & $52.46 \pm 2.09^{\#}$ & $12.26 \pm 0.59^{\wedge}$ & $4.76 \pm 0.20^{\wedge}$ \\
\hline $\begin{array}{c}\text { MPTP } \\
(20 \mathrm{mg} / \mathrm{kg}, \text { i.p. }) \\
+ \\
\text { Rasagiline } \\
\text { (0.1mg/kg,i.p.) }\end{array}$ & $46.10 \pm 2.47^{*}$ & $60.98 \pm 2.68 *$ & $15.00 \pm 0.54 *$ & $76.75 \pm 1.57^{\#}$ & $8.22 \pm 0.32 *$ & $0.72 \pm 0.08^{\#}$ \\
\hline $\begin{array}{c}\text { MPTP } \\
\text { (20mg/kg,i.p.) } \\
+ \\
\text { Nebivolol } \\
\text { (0.65mg/kg,i.p.) }\end{array}$ & $51.21 \pm 2.89^{\#}$ & $64.28 \pm 1.58 *$ & $13.24 \pm 0.90 *$ & $68.86 \pm 2.28^{\#}$ & $9.42 \pm 0.41 *$ & $1.27 \pm 0.07^{\#}$ \\
\hline $\begin{array}{c}\text { MPTP } \\
\text { (20mg/kg,i.p.) } \\
+ \\
\text { Nebivolol } \\
\text { (1.3mg/kg,i.p.) }\end{array}$ & $48.03 \pm 2.95^{*}$ & $58.98 \pm 2.89 *$ & $15.55 \pm 0.61^{\#}$ & $73.34 \pm 2.05^{\#}$ & $8.01 \pm 0.39 *$ & $1.06 \pm 0.03^{\#}$ \\
\hline
\end{tabular}

Values are expressed as Mean \pm SEM, $n=5 ;{ }^{\wedge} \mathrm{P}<0.0001,{ }^{\#} \mathrm{P}<0.001$ Vs Control; ${ }^{*} \mathrm{P}<0.001,{ }^{\#} \mathrm{P}<0.01$ Vs MPTP group (one-way ANOVA followed by Tukey's multiple comparison test) 
The results and the statistical analysis for the changes in brain tissue levels of lipid peroxidation (MDA), myeloperoxidation, nitrite and other antioxidant defence enzymes concentrations in isolated mice's whole brain homogenates after administration of Nebivolol are given in (Table No:2) In this, MPTP $(25 \mathrm{mg} / \mathrm{kg}$,i.p.) treated group showed significant $(P<0.0001)$ increase in the MDA, MPO, nitrite, brain proteins and significant reduction in the antioxidant enzymes such as CAT, GSH $(P<0.001, \mathrm{P}<0.01)$ when compared to the control group. Our test drug, Nebivolol at lower dose $(0.65 \mathrm{mg} / \mathrm{kg})$ and higher dose $(1.3 \mathrm{mg} / \mathrm{kg})$ produced significantly $(P<0.001, P<0.01)$ reduced the level of MDA, MPO, nitrite, brain proteins and Significant $(P<0.001, P<0.01)$ increased in the antioxidant enzymes such as CAT, GSH when compared to MPTP treated group.

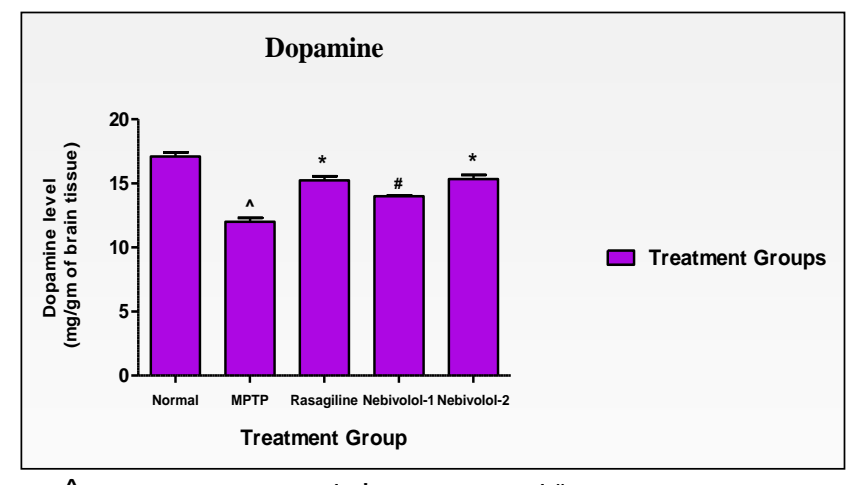

^ $\mathrm{P}<0.001$ Vs Control; ${ }^{*} \mathrm{P}<0.001$ and ${ }^{\#} \mathrm{P}<0.01$ Vs MPTP

Figure 1: Effect of Nebivolol on Dopamine

The results and the statistical analysis for the changes in Dopamine (DA) concentrations in isolated mice's whole brain homogenates after administration of Nebivolol are given in (Figure: 1 ) From this, the MPTP treated group was found to be significantly $(P<0.001)$ decrease the level of Dopamine concentration as compared to the control group; Treatment with Nebivolol (at both doses) significantly $(\mathrm{P}<0.001$ and $\mathrm{P}<0.01)$ increased the level of DA as compared to the MPTP treated group and also at higher doses of nebivolol showed almost near the level as the standard drug, Rasagiline.

\section{DISCUSSION}

PD is a progressive neurodegenerative disease caused by the destruction of dopaminergic neurons in the substantia nigra. The disease process is also associated with oxidative stress, apoptosis and inflammation. Parkinson's symptoms usuallly starts gradually and gets worse over time. As it progresses, people may have difficulty in walking and talking. In the present study, MPTP was preferred to induce PD symptoms in mice. MPTP is an established and valid method to induce PD symptoms in mice and caused a severe reduction of endogenous DA in substantia nigra and striatum. Effect of Nebivolol on MPTP induced parkinson disease in mice was investigated by using three behavioural models such as, Rotarod test, Hang test and Catatonic behavioral test.
These behavioral test was performed on the $7^{\text {th }}$ day after the drug administration, which was used to evaluate the motor deficits and bradykinesia, respectively. In this study, table: 1 depicts the retention time, hanging time was significantly decreased $(P<0.001)$ in the MPTP $(25 \mathrm{mg} / \mathrm{kg}$,i.p.) treated group compared to the vehicle control group suggesting that the initial lesions caused by MPTP to produced motor disability like bradykinesia. Existing evidence indicates that MPTP caused an unbalanced production of free radicals and dopamine depletion might contribute to the onset of movement disorders, such as Parkinsonism. This effects were significantly improved $(P<0.001)$ in standard drug, Rasagiline $(0.1 \mathrm{mg} / \mathrm{kg}$, i.p) treated group when compared to the MPTP treated group due to the antiparkinson's action of rasagiline. The test drug, Nebivolol $(0.65$ and $1.3 \mathrm{mg} / \mathrm{kg}$ ) treated groups showed significant variation in retention time $(P<0.01)$, hanging time $(P<0.05)$ in rotarod test, hang test respectively when compared to MPTP group. Among these, Nebivolol $1.3 \mathrm{mg} / \mathrm{kg}$ showed marked improvement $(P<0.01)$ in the locomotor ability compared to $0.65 \mathrm{mg} / \mathrm{kg}$ of Nebivolol. Hence the test group showed dose dependant effect.

Table 1: also reveals that the catatonic response. Under this test, the catatonic score was significantly $(P<0.0001)$ increased in all the time intervals in the MPTP $(25 \mathrm{mg} / \mathrm{kg}$,i.p.) treated animals when compared to the vehicle control group because of the administration of MPTP affected exercise abilities of mice, including moving distances and rearing frequencies. The striatum is known to be involved in head and forelimb motor control. Altered behavioural responses in mice, following DA depletion or striatal damage observed after MPTP intoxication in mice. Whereas, Rasagiline $(0.1 \mathrm{mg} / \mathrm{kg}$, i.p) and Nebivolol $(0.65$ and $1.3 \mathrm{mg} / \mathrm{kg}$ ) treated groups showed a significant $(P<0.001)$ reduction after 15 minutes time intervals when compared to the MPTP ( $25 \mathrm{mg} / \mathrm{kg}$,i.p.) treated group.

After performed the behavioural test, the animals were sacrificed by cervical dislocation and brain was collected and homogenate was centrifuged and the resultant cloudy supernatant liquid was used for the estimation of Dopamine, lipidperoxidation (MDA), myeloperoxidation, nitrite and other antioxidant defence enzymes. From the Table: 2 showed the antioxidant level, in this, the MPTP $(25 \mathrm{mg} / \mathrm{kg}$,i.p.) treated group showed significant $(P<0.0001)$ increase in the MDA, MPO, nitrite, brain proteins and significant reduction in the antioxidant enzymes such as CAT, GSH $(P<0.001, P<0.01)$ when compared to the control group. This happens due to the molecular mechanism by which the neurotoxin, MPTP is oxidized by mitochondrial MAO-B to give $\mathrm{MPDP}^{+}$and $\mathrm{MPP}^{+}$. $\mathrm{MPP}^{+}$is directly acting toxic metabolite that produces dopaminergic cell death through mitochondrial complex-1 inhibition and generation ROS (Tomas et al., 2011). Whereas Rasagiline $(0.1 \mathrm{mg} / \mathrm{kg}$, i.p) treated groups significantly $(P<0.001)$ decreased these levels compared to the MPTP treated groups by the mechanism of MAO-B 
inhibition, The test drug, Nebivolol (0.65 and $1.3 \mathrm{mg} / \mathrm{kg}$ ) treated groups significantly $(P<0.001)$ decreased these levels and significantly enhanced the CAT and GSH compared to the MPTP treated groups on dose dependent manner.

In this study, Figure: 1 depicts the concentration of Dopamine in whole brain homogenates. From this, MPTP $(25 \mathrm{mg} / \mathrm{kg}$,i.p.) treated group showed significant reduction $(P<0.001)$ in the dopamine level compared to the control group, whereas, our test drug at higher doses showed better and significantly $(P<0.001)$ increased the dopamine concentration in the brain homogenates

Hence in the present study, Nebivolol prevented the motor impairment in a dose dependent manner and also decreased the catatonic behaviour, which was altered by MPTP. Moreover, Lipid peroxidation, Myeloperoxidation and Nitrite levels in the mice brain tissue was decreased and increased the antioxidant defense enzymes (CAT and GSH) in Nebivolol treated groups compared to MPTP treated group. The loss of striatal dopamine was prevented which was slightly higher than the standard drug treated group. In all the behavioral and biochemical parameters, the nebivolol showed dose dependent effects. This beneficial effect was due to the following mechanism.

Nebivolol is a selective $\beta$-1-adrenoceptor blocker. Thus, there is a possibility that the antiparkinson's effect of Nebivolol may be due to blockade of $\beta$-adrenoceptor. Moreover, the research has also been reported that, Nebivolol has an antioxidant property by scavenging ROS, Nebivolol able to reduce the nitrite level in the brain by decreasing the oxidative stress, thus preventing the loss of dopaminergic neurons

\section{CONCLUSION}

The present study was concluded that Nebivolol exerts its beneficial effect in MPTP induced Parkinson's disease by virtue of its antioxidative, anti-inflammatory effect, and nebivolol also has increases the Dopamine levels (either by prevention of dopaminergic neurons, increase the synthesis of dopamine from Dopaminergic nerve endings or decrease metabolism of dopamine by monoamino oxidase (MAO)). Nevertheless, further studies are needed to explore the full potential of Nebivolol or the exact mechanism of Nebivolol in Parkinson's disease.

\section{REFERENCES}

1. Jellinger K. Pathology of Parkinson's disease. In: Calne DB, editors. Handbook of experimental pharmacology. Berlin: Springer; 1989; p.47-112.

2. Scherman D, Desnos C, Darchen F, Pollak P, JavoyAgid F, Agid Y., Striatal dopamine deficiency in Parkinson's disease: role of aging, Annals of Neurology, 1989; 26: 551-7.
3. Ebadi M, Srinivasan SK and Baxi MD, Oxidative stress and antioxidant therapy in Parkinson's disease, Progress in Neurobiology, 1996; 48: 1-19.

4. Jenner $\mathrm{P}$ and Olanow $\mathrm{CW}$, Oxidative stress and the pathogenesis of Parkinson's disease. Neurology. 1996; 47(3): S161-S170.

5. Troost R, Schwedhelm E, Rojczyk S, Tsikas D, Frolich JC, NBV decreases systematic oxidative stress in healthy volunteers, Journal of Clinical Pharmacology, 2000; 50: 377-99.

6. Sudha K, Rao AV, Rao A. Oxidative stress and antioxidants in epilepsy, International Journal of Clinical Chemistry, 2001; 303: 19-24.

7. Celik T, Iyisoy A, Kardesoglu E and Fici F, The antiinflammatory effects of nebivolol in human coronary smooth muscle cells: Clinical implications, International Journal of Cardiology, 2009; 133(3): 415-416

8. Ertugrul Uzar, The antioxidant and anti-apoptotic effects of nebivolol and zofenopril in a model of cerebral ischemia/reperfusion in rats, Progress in Neuro-Psychopharmacology and Biological Psychiatry, 2012; 36(1): 22-28.

9. Celik T, Iyisoy A, Kursaklioglu $H$, Kardesoglu E, Kilic $S$, Turhan H, Yilmaz MI, Ozcan O, Yaman H, Isik E and Fici $\mathrm{F}$, Comparative effects of nebivolol and metoprolol on oxidative stress, insulin resistance, plasma adiponectin and soluble P-selectin levels in hypertensive patients, Journal of Hypertension, 2006; 24(3): 591-6.

10. Radha Goel, Amit Goel, Anshu manocha, KK Pillai, Rashmi S and Srivastava, Influence of nebivolol on anticonvulsant effect of lamotrigine, Indian Journal of Pharmacology, 2009; 41(1): 41-46.

11. Paget GE, Barnes JM. In evaluation of drug activities: Pharmacometrics ed, Laurence DR and Bacharach AL. Academic Press, New York and London 1964.

12. Mohanasundari M, Sethupathy, S Sabesan M. The effect of Hypericum perforatum extract against the neurocemical and Behavioural changes induced by 1 methyl-4-phenyl-1, 2, 3, 6-tetrahydropyridine (MPTP) in mice, Indian Journal of Pharmacology. 2006; 38(4): 266-270.

13. Rozas G, Liste I, Guerra HJ, Labandesia JL, An automated rotarod method for quantitative drugfree evaluation of overall motor deficits in rat models of Parkinsonism, Brain Research, Brain Research Protocols, 1995; 245: 151-4.

14. Tillerson JL, Michael Caudle W, Reverson ME, Miller GW, Detection of behavioural impairments correlated to neurochemical deficits in mice treated with moderate dose of 1-methyl-4-phenyl-1,2,3,6- 
tetrahydropyridine, Experimental Neurology, 2002; 178: 80-90.

15. Kulkarni S.K, A. Arzi, P.N. Kaul, Modification of druginduced catatonia and tremors by quapazine in rats and mice, Japanese Journal of Pharmacology, 1980; 30: 129-135.

16. Sivaraman D, Panneerselvam $P$ and Muralidharan $P$, Memory and Brain Neurotransmitter Restoring Potential of Hydroalcoholic Extract of Ipomoea aquatica Forsk on Amyloid Beta A $(25-35)$ Induced Cognitive Deficits in Alzheimer's Mice. International Journal of Pharmacology, 2016; 12: 52-65.

17. Wills ED, Mechanism of lipid peroxide formation in animal tissues, Biochemical Journal, 1966; 99:66776.

Source of Support: The author(s) received no financial support for the research, authorship, and/or publication of this article.

Conflict of Interest: The author(s) declared no potential conflicts of interest with respect to the research, authorship, and/or publication of this article.

For any question relates to this article, please reach us at: editor@globalresearchonline.net New manuscripts for publication can be submitted at: submit@globalresearchonline.net and submit_ijpsrr@rediffmail.com 